\title{
ASSOCIATION OF APO E POLYMORPHISM WITH BLOOD PRESSURE IN MINAHASAN PEOPLE
}

\author{
Frans E. Wantania \\ Reginald L. Lefrandt
}

\author{
Department of Cardiology and Vascular Medicine \\ Faculty of Medicine, University of Sam Ratulangi Manado \\ Email: Akuaku_ukauka@ymail.com
}

\begin{abstract}
Abstrak: Polimorfisme apolipoprotein E berhubungan dengan aterosklerosis, tetapi kaitannya dengan hipertensi masih belum jelas. Hasil variasi ini mungkin terdapat pada populasi yang berbeda. Sebagian kecil dari variasi ini merupakan hubungan yang positif antara tebal tunika intima-media karotis (diukur dengan ultrasound) dan alele ApoE4 versus ApoE3 yang telah didokumentasi untuk pasien tanpa diabetes dan asimtomatik. Tujuan studi ini untuk meneliti hubungan antara alele ApoE4 dan tekanan darah pada orang Minahasa. Studi ini merupakan studi kontrol kasus retrospektif. Populasi terdiri dari 60 subyek, 30 kasus hipertensi dan 30 individu sehat. Untuk analisis data digunakan Fisher Exact Test. Hasil studi memperlihatkan frekuensi ApoE4 lebih tinggi secara bermakna pada pasien hipertensi dari pada kelompok kontrol ( $\mathrm{p}<0,05)$. Simpulan: pada orang Minahasa, genotip ApoE4 berhubungan dengan hipertensi. Penelitian lanjut dengan populasi yang lebih besar diperlukan untuk menunjang hasil studi ini.
\end{abstract}

Kata kunci: apolipoprotein E4, tekanan darah, orang Minahasa

\begin{abstract}
Apolipoprotein E polymorphism is related to atherosclerosis while its association with hypertension is still unclear. These resulting variations may possibly be attributed to different populations. A small part of these variations are positive associations between carotid intima-media thickness, measured by ultrasound, and ApoE4 versus ApoE3 allele has been documented for asymptomatic, nondiabetic patients. The purpose of this study was to investigate the association between ApoE4 alleles and blood pressure in Minahasan people. This was a retrospective case-control study. The population of this study consisted of 60 subjects including 30 hypertension cases and 30 healthy subjects. We used the Fisher Exact Test to analyze the data. The result showed that the ApoE4 frequencies were significantly higher in hypertension patients than in the control group $(\mathrm{p}<0.05)$. Conclusion: in Minahasan people, ApoE4 genotype is associated with hypertension. Further investigation with a larger population is needed to confirm this study.
\end{abstract}

Keywords: apolipoprotein E4, blood pressure, Minahasan people

Apolipoprotein E (ApoE) polymorphism is related to atherosclerosis while its association with the hypertension is still unclear. ${ }^{1}$ These variations in result may possibly be attributed to the different population, but a small, the positive association between carotid intima media thickness, measured by ultrasound, and ApoE4 versus ApoE3 allele has been documented for asymp- tomatic, nondiabetic patients. ${ }^{2}$ The objecttive of this study was to investigate the association of ApoE4 alleles with blood pressure in Minahasan people.

There is a wealth of literature on the ApoE polymorphism and attempts to associate this locus with numerous phenotypes; most of it is related to cardiovascular disease or cardiovascular disease risk factors. 
The citations that follow were selected to give a balanced, although not exhaustive view of genotype-phenotype studies. Apo $\varepsilon$ has been one of the most thoroughly studied genetic polymorphisms, particularly for its effects on lipid profiles and coronary arterial disease (CAD) risk. In comparisons made to determine risk, the homozygous * $\varepsilon 3 / 3$ genotype is used as the referent. In general, ${ }^{*} \varepsilon 2$ lowers total cholesterol levels and ${ }^{*} \varepsilon 4$ raises them. The ${ }^{*} \varepsilon 2$ cholesterol-lowering effect is 2-3 times that of the ${ }^{*} \varepsilon 4$ cholesterol-raising effect. On average, ${ }^{*} \varepsilon 2$ lowers cholesterol levels. ${ }^{3,4}$

\section{METHODS}

This study is a retrospective case-control study. The study population consisted of 60 subjects including 30 hypertension cases and 30 healthy subjects. We used the Fisher Exact Test to analyze the data. The samples were Minahasan hypertension outpatients in Prof Dr R.D. Kandou Hospital Manado. Sampling method was carried out consecutively until the required number was enough. Data consisted of age, blood pressure, body weight, lipid profile, and apoE alleles.

\section{RESULT AND DISCUSSION}

The ApoE4 frequencies were significantly higher in the hypertension patients than in the control group ( $\mathrm{p}<0.05)$.

Arterial stiffness and hypertension are the most important risk factors for cardiovascular diseases. ${ }^{5}$ Several studies have demonstrated association of these with the metabolic profile. ${ }^{6,7}$ Several studies failed to demonstrate an association between ApoE polymorphisms with blood pressure phenotypes and arterial stiffness. Fuzikawa et $\mathrm{al}^{8}$ studied 1,406 Brazilian elderly individuals and found no association between ApoE genotype and hypertension. Similarly, Carmo-Martins et al $^{9}$ studied 672 Portuguese subjects and failed to demonstrate an association with blood pressure. Focusing on the arterial stiffness, studies have shown that the unfavorable lipid profile is associated with lower arterial complacence due to reduced nitric oxide (NO) bioavailability induced by dyslipidemia. ${ }^{10}$

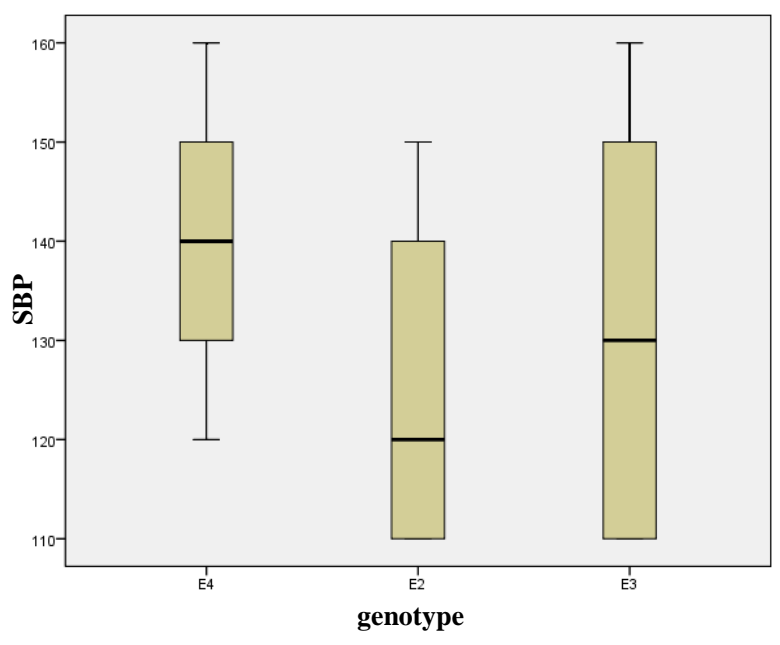

Diagram 1. Distribution of systolic blood pressure according to ApoE alleles

Tabel 1. Blood pressure characteristic according to ApoE alleles

\begin{tabular}{ccccc}
\hline $\begin{array}{c}\text { Parameter } \\
\text { (blood pressure) }\end{array}$ & $\begin{array}{c}\text { E2 } \\
(\text { Mean } \pm \text { SD })\end{array}$ & $\begin{array}{c}\text { E3 } \\
(\text { Mean } \pm \text { SD })\end{array}$ & $\begin{array}{c}\text { E4 } \\
(\text { Mean } \pm \text { SD })\end{array}$ & P value \\
\hline Systolic (SBP) & $123.33 \pm 15.81$ & $131.46 \pm 17.26$ & $139.58 \pm 13.67$ & 0.026 \\
Diastolic (DBP) & $78.33 \pm 9.35$ & $81.95 \pm 7.82$ & $85.63 \pm 7.98$ & 0.052 \\
\hline
\end{tabular}




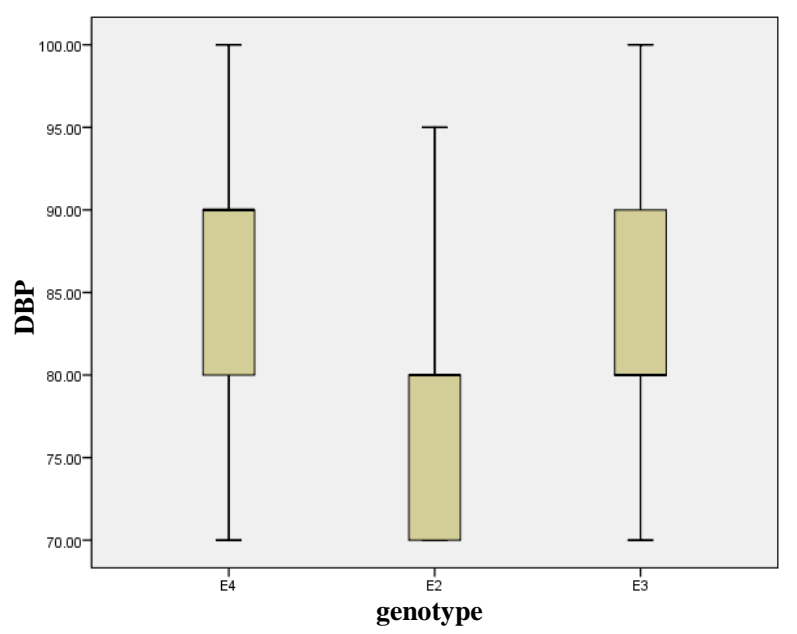

Diagram 2. Distribution of diastolic blood pressure according to ApoE alleles

Thus, we expected $\varepsilon 4$ allele carriers of the ApoE polymorphism would have a higher arterial stiffness when compared to non-apoE4 allele carriers. This was evident in the studies involving the ApoE polymorphism with arterial stiffness, but the phenotype remained scarce in the literature. Thereby, further studies involving the ApoE polymorphism with arterial stiffness phenotype are needed to clarify these issues.

Various studies of vessel pathology have been conducted by using postmortem specimens, angiographic findings, and ultrasound measurements of intima-media thickness. In one autopsy study of young (aged 15-34 years) Caucasian and AfricanAmerican males, the apo $\varepsilon$ genotype accounted for 5.7 percent of the observed variation in lesions of the thoracic aorta in Caucasians and 5.9 percent in AfricanAmericans, and for 5.9 percent of the variation in lesions of the abdominal aorta in Caucasians and 7.0 percent in AfricanAmericans. ${ }^{11}$ Adjustment for cholesterol levels did not appreciably change these apo $\varepsilon$ genotypic effects. In a study of the right and left anterior descending coronary arteries and aortae from 700 male autopsy cases (Helsinki Sudden Death Study) ranging in age from 33 to 70 years, Ilveskoski et al. concluded that apo ${ }^{*} \varepsilon 4$ was a significant genetic risk factor for CAD. ${ }^{12}$
A population-based autopsy study had proved that the ApoE4 genetic variant was associated with pathological intimal thickening and atherosclerotic burden in the carotid arteries. ${ }^{13}$ It appears that the association of the ApoE4 allele with CAD could be due to its default action in protecting lipoproteins and the endothelial cells of coronary arteries from oxidative damage. And based on genetic deficiency, atherosclerosis appears to be accelerated by the interactions among the ApoE4 allele and other CAD risk factors such as elevated lipid levels, smoking, obesity, and hypertension. Therefore, the ApoE4 allele is not only an independent risk factor for CAD, but also an important genetic marker predicting severity of CAD. ${ }^{14,15}$

The role of ApoE as a ligand for receptor mediated clearance of chylomicron and VLDL remnants is of vital significance; ApoE participates in the hepatic clearance of chylomicron remnants and other ApoE containing lipoproteins. Another role of ApoE is in reverse cholesterol transport. The dual role of ApoE is crucial for clearing the plasma of chylomicron remnants and excess cholesterol. The ApoE can also bind to LDL receptorrelated proteins (LRPs), VLDL receptors, heparin and proteoglycans. By binding to heparin and heparin-like glycosoaminoglycans present in the matrix of arterial walls, ApoE has a possible role in smooth muscle biology in which muscle cell proliferation and migration in the intima is characteristic of atherosclerotic vascular disease. $^{16-18}$

Karvonen et al $^{19}$ reported the interaction between ApoE genotype and smoking in relation to cardiovascular disease. Their study included hypertensive men and agematched normotensive controls who participated in the population based Olulu Project Elucidating Risk of Atherosclerosis project (OPERA). In hypertensive men, there was a significant interaction between the presence of the $\varepsilon 4$ allele and smoking in relation to mean carotid intima-media thickness (IMT) whereas no effect of the $\varepsilon 4$ allele on carotid IMT was seen in 
hypertensive non-smokers. The presence of $\varepsilon 4$ was positively associated with mean carotid IMT in hypertensive smokers, further IMT increased with age in hypertensive smokers carrying the $\varepsilon 4$ allele but to a lesser extent in non-carrier, non-smokers and normotensive subjects. The authors suggested that the interaction between ApoE genotype and smoking can be due to the combined pro-oxidant effects of smoking and the decreased protection against oxidation which has been attributed more to the $\varepsilon 4$ allele than the $\varepsilon 2$ and $\varepsilon 3$ allele. ${ }^{19,20}$

\section{CONCLUSION}

In Minahasan people, ApoE4 genotype is associated with hypertension. Further investigation with a larger population is needed to confirm this study.

\section{REFERENCES}

1. Huang Y, Liu XQ, Rall SC Jr, Taylor JM, Eckardstein A, Assmann, et al. Overexpression and accumulation of apoE lipoprotein $\mathrm{E}$ as a cause of hypertriglyceridemia. J Biol Chem. 1998; 273:26388-93.

2. Cattin L, Fisicaro M, Tonizzo M, Valenti M, Danek GM, Fondsda M, et al. Polymorphism of the apolipoprotein E gene and early carotid atherosclerosis defined by ultrasonography in asymptomatic adults. Arterioscler Thromb Vasc Biol. 1997;17:91-4.

3. Hallman DM, Boerwinkle E, Saha N, Sandholzer C, Menzel HJ, Csazar A, et al. The apolipoprotein E polymorphism: a comparison of allele frequencies and effects in nine populations. Am J Hum Genet. 1991;49:338-49.

4. Grocott HP, Newman MF, El-Moalem H, Bainbridge D, Butler, BAA, Laskowitz DT, et al. Apolipoprotein E genotype differentially influences the proinflammatory and anti-inflammatory response to cardiopulmonary bypass. J Thoracic Cardio Vasc Surg. 2001;122: 622-3.

5. Meaume S, Benetos A, Henry OF, Rudnichi A, Safar ME: Aortic pulse wave velocity predicts cardiovascular mortality in subjects $>70$ years of age. Arterioscler Thromb Vasc Biol. 2001; 21(12):2046-2050.

6. Zanchetti A: Hyperlipidemia in the hypertensive patient. Am J Med. 1994, 96(6A):3S-8S.

7. Pannier BM, Cambillau MS, Vellaud V, Atger V, Moatti N, Safar ME: Abnormalities of lipid metabolism and arterial rigidity in young subjects with borderline hypertension. Clin Invest Med. 1994;17(1):42-51.

8. Fuzikawa AK, Peixoto SV, Taufer M, Moriguchi EH, Lima-Costa MF: Association of ApoE polymorphisms with prevalent hypertension in 1406 older adults: the Bambui Health Aging Study (BHAS). Braz J Med Biol Res. 2008; 41(2):89-94.

9. Carmo Martins M, Lima Faleiro L, Rodrigues MO, Albergaria I, Fonseca A: Influence of the APOE genotypes in some atherosclerotic risk factors. Acta Med Port. 2008; 21(5):433-440.

10. Vogel RA, Corretti MC, Gellman J: Cholesterol, cholesterol lowering, and endothelial function. Prog Cardiovasc Dis. 1998;41(2):117-136.

11. Hixson JE. Apolipoprotein E polymorphisms affect atherosclerosis in young males. Pathobiological determinants of atherosclerosis in youth (PDAY) research group. Arterioscler Thromb. 1991;11:1237-44.

12. Ilveskoski E, Perola $M$, Lehtimäki T, Laippala P, Savolainen V, Pajarinen J, et al. Age-dependent association of apolipoprotein E genotype with coronary and aortic atherosclerosis in middle-aged men: an autopsy study. Circulation. 1999;100:608-13.

13. Magyar MT, Sziksai Z, Balla J, Valikovics A, Kappelmayer J, ImreS, et al. Early-onset carotid atherosclerosis is associated with increase intima-media thickness and elevated serum levels of inflammatory parameters. Stroke. 2003;34:58-63.

14. Roman MJ, Pickering TG, Schwartz JE, Pini R, and Devereux RB. Relation of blood pressure variability to carotid atherosclerosis and carotid artery and left ventricular hypertrophy. Arteriscler Thromb Vasc Biol. 2001;21:1507-10. 
15. Simons PCG, Algra A, Bots ML, Grobbe DE, and van der Graaf $Y$. Common carotid intima-media thickness and arterial stiffness. Stroke. 2002;33: 1255-60.

16. Kolovou GD, Anagnostopoulou KK, Kostakou P, Giannakopoulou V, Mihas C, Hatzigeorgiou GI, et al. Apolipoprotein E Gene polymorphism and obesity status in middle-aged men with coronary heart disease. In vivo. 2009;23:33-40.

17. Eichner JE, Dunn ST, Perveen G, Thompson DM, Stewart KE, and Stroehla BC. Apolipoprotein E polymorphism and cardiovascular disease: A HuGE review. Am J Epidemiol. 2002:155:487-95.

18. Grocott HP, Newman MF, El-Moalem H,
Bainbridge D, Butler, BAA, Laskowitz DT, et al. Apolipoprotein E genotype differentially influences the proinflammatory and anti-inflammatory response to cardiopulmonary bypass. $\mathbf{J}$ Thoracic Cardio Vasc Surg. 2001;122: 622-3.

19. Karvonen J, Kauma $H$, Kervinen $K$, Ukkola O, Rantala M, Päivänsalo $M$. Apolipoprotein E polymorphism affects carotid artery atherosclerosis in smoking hypertensive men. J Hyperten. 2002;20:2371-8.

20. Humphries SE, Talmud PJ, Hawe E, Bolla M, Day INM, Miller GJ. Apolipoprotein E4 and coronary heart disease in middle aged men who smoke: a prospective study. Lancet. 2001;358:115-9. 